\title{
Single Crystal X-Ray Diffraction Studies on Magnetic $\mathrm{Yb}_{5} \mathrm{Co}_{4} \mathrm{Ge}_{10}{ }^{*}$
}

\author{
Udumula Subbarao, Sebastian C. Peter ${ }^{\#}$ \\ New Chemistry Unit, Jawaharlal Nehru Centre for Advanced Scientific Research, Bangalore, India \\ Email: " sebastiancp@jncasr.ac.in \\ Received January 15, 2013; revised March 4, 2013; accepted April 12, 2013
}

Copyright (C) 2013 Udumula Subbarao, Sebastian C. Peter. This is an open access article distributed under the Creative Commons Attribution License, which permits unrestricted use, distribution, and reproduction in any medium, provided the original work is properly cited.

\begin{abstract}
The high quality single crystals of $\mathrm{Yb}_{5} \mathrm{Co}_{4} \mathrm{Ge}_{10}$ have been grown by the indium metal flux method and characterized by means of single crystal X-ray diffraction data. $\mathrm{Yb}_{5} \mathrm{Co}_{4} \mathrm{Ge}_{10}$ crystallizes in the $\mathrm{Sc}_{5} \mathrm{Co}_{4} \mathrm{Si}_{10}$ structure type, tetragonal space group $P 4 / \mathrm{mbm}$ and lattice constants are $a=b=12.6369(18) \AA$ and $c=4.1378(8) \AA$. Crystal structure of $\mathrm{Yb}_{5} \mathrm{Co}_{4} \mathrm{Ge}_{10}$ composed of three-dimensional $\left[\mathrm{Co}_{4} \mathrm{Ge}_{12}\right]$ network having five, six and eight membered rings. The three non-equivalent $\mathrm{Yb}$ atoms are sandwiched in three different channels created by the $\left[\mathrm{Co}_{4} \mathrm{Ge}_{12}\right]$ network. Based on the bond length analysis from the crystallographic information, we confirmed that $\mathrm{Yb} 1$ and $\mathrm{Yb} 2$ atoms are in the trivalent magnetic state and $\mathrm{Yb} 3$ is in the divalent non-magnetic state.
\end{abstract}

Keywords: X-Ray Diffraction; Single Crystal; Intermetallics; Ytterbium

\section{Introduction}

The ternary intermetallic compounds of general formula $R E_{5} \mathrm{~T}_{4} \mathrm{X}_{10}(R E=$ rare earths; $\mathrm{T}=\mathrm{Co}, \mathrm{Ni}, \mathrm{Rh}, \mathrm{Ir}$ and $\mathrm{Os}$ and $\mathrm{X}=\mathrm{Si}, \mathrm{Ge}, \mathrm{Sn}$ ) have been reported mostly for their interesting physical properties [1-22]. These compounds crystallize in the tetragonal $\mathrm{Sc}_{5} \mathrm{Co}_{4} \mathrm{Si}_{10}$ structure type having $P 4 / \mathrm{mbm}$ space group [1]. As per Pearson crystallographic database [23] and inorganic crystal structure database [24], there are 37 compounds reported within the family of $R E_{5} \mathrm{~T}_{4} \mathrm{X}_{10}$ compounds and are listed in Table 1 . Among them only three were studied for the crystal structure from the single crystal XRD data, including our recent discovery of $\mathrm{Yb}_{5} \mathrm{Ni}_{4} \mathrm{Ge}_{10}$ mixed valent $\mathrm{Yb}$ atoms [2]. However, the majority of these compounds were studied for their physical properties. For examples, the non-magnetic $R E_{5} \mathrm{~T}_{4} \mathrm{X}_{10}(R E=$ rare earths; $\mathrm{T}=\mathrm{Co}$, $\mathrm{Rh}, \mathrm{Ir}$, and $\mathrm{Os} ; \mathrm{X}=\mathrm{Ge}, \mathrm{Si}$ ) compounds were reported as superconductors at low temperatures [5,12,17-19]. The $R E_{5} \mathrm{Rh}_{4} \mathrm{X}_{10}(R E=\mathrm{Gd}, \mathrm{Tb}, \mathrm{Dy}, \mathrm{Ho}, \mathrm{Er}, \mathrm{Tm} ; \mathrm{X}=\mathrm{Si}, \mathrm{Ge}$, $\mathrm{Sn})$ and $\mathrm{Dy}_{5} \mathrm{Ir}_{4} \mathrm{Si}_{10}$ compounds were reported for their interesting magnetic properties and all of them order either ferromagnetically or antiferromagnetically at low temperature [11,18,20,21].

Katoh et al. synthesized the $\mathrm{Yb}_{5} \mathrm{Co}_{4} \mathrm{Ge}_{10}$ compound in

${ }^{*}$ Crystallographic information files (CIF).

${ }^{\#}$ Corresponding author. the polycrystalline nature using Bridgman method [22]. They have proposed the mixed valent nature of $\mathrm{Yb}$ in $\mathrm{Yb}_{5} \mathrm{Co}_{4} \mathrm{Ge}_{10}$ based on the magnetic susceptibility data. In order to understand the structure-property relationship, we need to study the complete crystallography analysis from a high quality single crystal. The chemical bonding nature obtained from the crystal structure can be used to explain the valency of the $\mathrm{Yb}$ atoms. Recently, molten metal fluxes have been used as an excellent alternative to the conventional synthetic methods for the exploratory synthesis of new rare earth intermetallic compounds, as well as single crystal growth of already reported compounds [25-39].

In this paper, we report the single crystal growth of $\mathrm{Yb}_{5} \mathrm{Co}_{4} \mathrm{Ge}_{10}$ using liquid indium metal flux technique. The crystal structure of this compound has refined from the single crystal XRD data. We also discuss the crystal structure and chemical bonding of $\mathrm{Yb}_{5} \mathrm{Co}_{4} \mathrm{Ge}_{10}$ and compared with other compounds.

\section{Experimental Section}

\subsection{Synthesis}

The following reagents were used as purchased without further purification: $\mathrm{Yb}$ (in the form of metal pieces cut from metal chunk, 99.99\% Alfa Aesar), Co (powder, 
Table 1. The list of the $R E_{5} T_{4} X_{10}(R E=$ Rare earth, $T=C o$, $\mathrm{Rh}, \mathrm{Ir}$, Os and $\mathrm{Ni}$; $X=\mathrm{Si}$, Ge and $\mathrm{Sn}$ ) compounds reported.

\begin{tabular}{|c|c|c|c|c|}
\hline Compound & $a(\AA)$ & $c(\AA)$ & Vol. $\left(\AA^{3}\right)$ & Ref. \\
\hline $\mathrm{Y}_{5} \mathrm{Os}_{4} \mathrm{Ge}_{10}$ & $13.012(4)$ & $4.2927(4)$ & 726.8 & {$[3,4]$} \\
\hline $\mathrm{Gd}_{5} \mathrm{Rh}_{4} \mathrm{Ge}_{10}$ & $12.987(8)$ & $4.299(3)$ & 725.0 & [5] \\
\hline $\mathrm{Dy}_{5} \mathrm{Os}_{4} \mathrm{Ge}_{10}$ & $13.034(2)$ & $4.299(3)$ & 725.8 & [6] \\
\hline $\mathrm{Ho}_{5} \mathrm{Os}_{4} \mathrm{Ge}_{10}$ & $12.984(3)$ & $4.2820(6)$ & 721.9 & {$[7,8]$} \\
\hline $\mathrm{Ho}_{5} \mathrm{Os}_{4} \mathrm{Ge}_{10}$ & $12.984(3)$ & $4.2820(6)$ & 721.9 & [9] \\
\hline $\mathrm{Er}_{5} \mathrm{Rh}_{4} \mathrm{Ge}_{10}$ & $12.889(8)$ & $4.236(3)$ & 707.7 & [5] \\
\hline $\mathrm{Er}_{5} \mathrm{Ir}_{4} \mathrm{Ge}_{10}$ & $12.865(9)$ & $4.278(3)$ & 694.8 & [5] \\
\hline $\mathrm{Tm}_{5} \mathrm{Co}_{4} \mathrm{G}_{10}$ & $12.622(9)$ & $4.139(4)$ & 659.4 & [5] \\
\hline $\mathrm{Tm}_{5} \mathrm{Rh}_{4} \mathrm{Ge}_{10}$ & $12.868(9)$ & $4.230(3)$ & 700.4 & [5] \\
\hline $\mathrm{Tm}_{5} \mathrm{Ir}_{4} \mathrm{Ge}_{10}$ & $12.846(8)$ & $4.267(3)$ & 704.1 & [5] \\
\hline $\mathrm{Yb}_{5} \mathrm{Co}_{4} \mathrm{G}_{10}$ & $12.645(9)$ & $4.138(4)$ & 661.6 & [5] \\
\hline $\mathrm{Yb}_{5} \mathrm{Co}_{4} \mathrm{G}_{10}$ & $12.637(2)$ & $4.1378(8)$ & 660.7 & * \\
\hline $\mathrm{Yb}_{5} \mathrm{Ni}_{4} \mathrm{G}_{10}$ & $12.672(2)$ & $4.1598(8)$ & 667.9 & [2] \\
\hline $\mathrm{Yb}_{5} \mathrm{Rh}_{4} \mathrm{Ge}_{10}$ & $12.886(9)$ & $4.234(3)$ & 703.0 & [5] \\
\hline $\mathrm{Yb}_{5} \mathrm{Ir}_{4} \mathrm{Ge}_{10}$ & $12.877(9)$ & $4.285(3)$ & 710.5 & [5] \\
\hline $\mathrm{Lu}_{5} \mathrm{Co}_{4} \mathrm{G}_{10}$ & $12.606(8)$ & $4.125(3)$ & 655.5 & [5] \\
\hline $\mathrm{Lu}_{5} \mathrm{Rh}_{4} \mathrm{Ge}_{10}$ & $12.850(80$ & $4.208(3)$ & 694.8 & [5] \\
\hline $\mathrm{Lu}_{5} \mathrm{Ir}_{4} \mathrm{Ge}_{10}$ & $12.831(9)$ & $4.252(3)$ & 700.0 & [5] \\
\hline $\mathrm{Sc}_{5} \mathrm{Co}_{4} \mathrm{Si}_{10}$ & $12.013(3)$ & $3.936(2)$ & 568.0 & {$[10]$} \\
\hline $\mathrm{Sc}_{5} \mathrm{Co}_{4} \mathrm{Si}_{10}$ & $12.01(1)$ & $3.936(5)$ & 567.7 & [1] \\
\hline $\mathrm{Sc}_{5} \mathrm{Rh}_{4} \mathrm{Si}_{10}$ & $12.344(2)$ & $4.039(1)$ & 615.4 & [11] \\
\hline $\mathrm{Sc}_{5} \mathrm{Rh}_{4} \mathrm{Si}_{10}$ & $12.330(3)$ & $4.030(2)$ & 612.6 & [1] \\
\hline $\mathrm{Sc}_{5} \mathrm{Ir}_{4} \mathrm{Si}_{10}$ & $12.335(2)$ & $4.083(1)$ & 621.2 & {$[1,11]$} \\
\hline $\mathrm{Y}_{5} \mathrm{Ir}_{4} \mathrm{Si}_{10}$ & $12.599(2)$ & $4.234(3)$ & 672.0 & [12] \\
\hline $\mathrm{Dy}_{5} \mathrm{Ir}_{4} \mathrm{Si}_{10}$ & $12.577(2)$ & $4.234(1)$ & 670.2 & {$[13,14]$} \\
\hline $\mathrm{Ho}_{5} \mathrm{Ir}_{4} \mathrm{Si}_{10}$ & $12.558(2)$ & $4.218(1)$ & 665.1 & [13] \\
\hline $\mathrm{Er}_{5} \mathrm{Ir}_{4} \mathrm{Si}_{10}$ & $12.540(2)$ & $4.208(1)$ & 661.7 & [13] \\
\hline $\mathrm{Tm}_{5} \mathrm{Ir}_{4} \mathrm{Si}_{10}$ & $12.513(2)$ & $4.197(1)$ & 657.1 & [13] \\
\hline $\mathrm{Yb}_{5} \mathrm{Ir}_{4} \mathrm{Si}_{10}$ & $12.503(3)$ & $4.182(2)$ & 653.7 & [13] \\
\hline $\mathrm{Lu}_{5} \mathrm{Rh}_{4} \mathrm{Si}_{10}$ & $12.502(2)$ & $4.137(2)$ & 646.6 & [1] \\
\hline $\mathrm{Lu}_{5} \mathrm{Ir}_{4} \mathrm{Si}_{10}$ & $12.475(2)$ & $4.171(1)$ & 649.1 & [1] \\
\hline $\mathrm{La}_{5} \mathrm{Ir}_{4} \mathrm{Sn}_{10}$ & $14.088(10)$ & $4.690(4)$ & 930.8 & {$[15]$} \\
\hline $\mathrm{Ce}_{5} \mathrm{Rh}_{4} \mathrm{Sn}_{10}$ & $14.053(12)$ & $4.621(5)$ & 912.5 & {$[15]$} \\
\hline $\mathrm{Ce}_{5} \mathrm{Ir}_{4} \mathrm{Sn}_{10}$ & $14.027(15)$ & $4.648(8)$ & 914.5 & {$[15]$} \\
\hline $\mathrm{Pr}_{5} \mathrm{Rh}_{4} \mathrm{Sn}_{10}$ & $14.035(13)$ & $4.612(4)$ & 908.4 & {$[15]$} \\
\hline $\mathrm{Pr}_{5} \mathrm{Ir}_{4} \mathrm{Sn}_{10}$ & $13.993(16)$ & $4.632(6)$ & 906.9 & {$[15]$} \\
\hline $\mathrm{Nd}_{5} \mathrm{Rh}_{4} \mathrm{Sn}_{10}$ & $13.992(17)$ & $4.588(7)$ & 898.2 & {$[15]$} \\
\hline $\mathrm{Sm}_{5} \mathrm{Rh}_{4} \mathrm{Sn}_{10}$ & $13.926(16)$ & $4.554(6)$ & 883.1 & [15] \\
\hline $\mathrm{Ho}_{5} \mathrm{Rh}_{4} \mathrm{Ge}_{10}$ & $12.9336(9)$ & $4.2596(6)$ & 712.5 & [16] \\
\hline
\end{tabular}

*This work.

99.99\% Alfa Aesar), Ge (pieces, 99.999\% Alfa Aesar) and In (shots, $99.99 \%$ Alfa-Aesar). High quality single crystals of $\mathrm{Yb}_{5} \mathrm{Co}_{4} \mathrm{Ge}_{10}$ were obtained by combining ytterbium metal $(0.3 \mathrm{~g})$, cobalt powder $(0.1 \mathrm{~g})$, germanium $(0.3)$ and indium shots $(2 \mathrm{~g})$ in an alumina crucible. The crucible was placed in a $13 \mathrm{~mm}$ fused silica tube which was flame sealed under a vacuum of $10^{-5}$ torr, to prevent oxidation during heating. The reactants were then heated to $1173 \mathrm{~K}$ over $8 \mathrm{~h}$, and maintained at that temperature for $2 \mathrm{~h}$ to allow proper homogenization, then cooled down to $1073 \mathrm{~K}$ in $2 \mathrm{~h}$ and kept at this temperature for 72 h. Finally, the sample was allowed to cool slowly to 303 $\mathrm{K}$ over $48 \mathrm{hrs}$. No reactions with the alumina crucible material could be detected. The reaction product was isolated from the excess indium flux by heating at $673 \mathrm{~K}$ and subsequently centrifuging through a coarse frit. Any remaining flux was removed by immersion and sonication in glacial acetic acid for $24 \mathrm{~h}$. The final crystalline product was rinsed with water and dried with acetone. A few small gray rod-shaped crystals of $\mathrm{Yb}_{5} \mathrm{Co}_{4} \mathrm{Ge}_{10}$ carefully selected for the elemental analysis and single crystal XRD data collection. $\mathrm{Yb}_{5} \mathrm{Co}_{4} \mathrm{Ge}_{10}$ is stable in air and no decomposition was observed even after several months.

\subsection{Elemental Analysis}

Semi-quantitative microanalyses were performed on the single crystals obtained from the flux techniques using a scanning Leica 220i electron microscope (SEM) equipped with Bruker $129 \mathrm{eV}$ energy dispersive X-ray analyzer (EDS). Data were acquired with an accelerating voltage of $20 \mathrm{kV}$ and in $60 \mathrm{~s}$ accumulation time. The EDS analysis performed on visibly clean surfaces of the single crystals obtained from the flux method indicated that the atomic composition was close to 5:4:10 in good agreement with the composition obtained from the single crystal data refinement. A typical SEM image of rod-like crystals of $\mathrm{Yb}_{5} \mathrm{Co}_{4} \mathrm{Ge}_{10}$ grown from the flux synthesis is shown in Figure 1.

\subsection{Single Crystal X-Ray Diffraction}

Single crystal structural data of $\mathrm{Yb}_{5} \mathrm{Co}_{4} \mathrm{Ge}_{10}$ was collected at room temperature on rod shaped single crystals using a Bruker Smart-CCD diffractometer equipped with

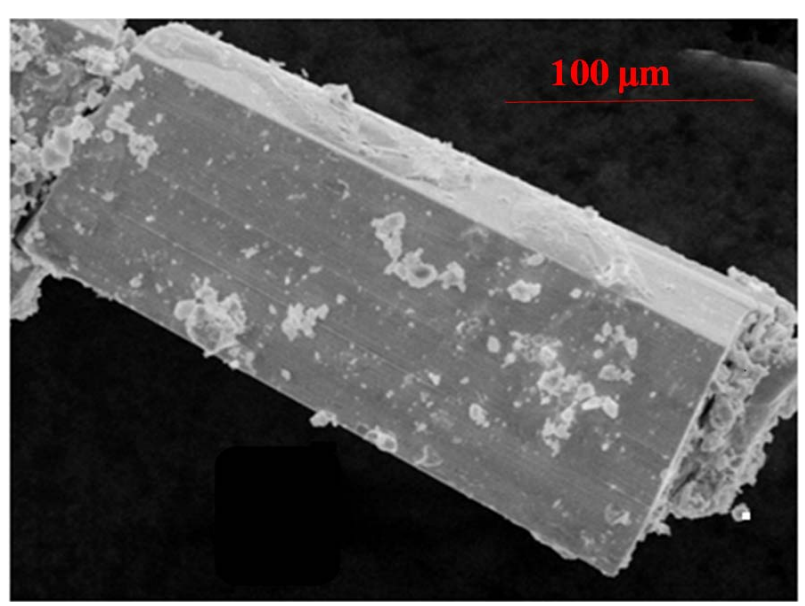

Figure 1. Typical SEM image of $\mathrm{Yb}_{5} \mathrm{Co}_{4} \mathrm{Ge}_{10}$ single crystal grown from In flux. 
a normal focus, $2.4 \mathrm{~kW}$ sealed tube X-ray source with graphite monochromatic Mo-K $\alpha$ radiation $(\lambda=0.71073$ $\AA$ ) operating at $50 \mathrm{kV}$ and $30 \mathrm{~mA}$, with $\omega$ scan mode. A crystal of suitable size $(0.5 \times 0.05 \times 0.05 \mathrm{~mm})$ was cut from a small rod shape crystal and mounted on a thin glass $(\sim 0.1 \mathrm{~mm})$ fiber with commercially available super glue. A full sphere of 60 frames was acquired up to $57.87^{\circ}$ in $2 \theta$. The individual frames were measured with w steps of $0.50^{\circ}$ and an exposure time of $20 \mathrm{~s}$ per frame. The programme SAINT [40] was used for integration of diffraction profiles and absorption correction was made with SADABS programme [41]. The systematic absences were leading to the centrosymmetric space group $P 4 / \mathrm{mbm}$. However, the Platon program within WinGx system, ver. 1.80.05 [42] was used to check the additional symmetry, and this was not suggesting any additional symmetry. The structure was solved by SHELXS 97 [43] and refined by a full matrix least-squares method using SHELXL [44] with anisotropic atomic displacement parameters for all atoms. Packing diagrams were generated with Diamond [45]. In order to check for the correct composition, the occupancy parameters were refined in a separate series of least-squares cycles. All bond lengths are within the acceptable range compared to the theoretical values. Details of the crystallographic data are given in Tables 2 to 5.

Table 2. Crystal data and structure refinement for $\mathrm{Yb}_{5} \mathrm{Co}_{4} \mathrm{Ge}_{10}$.

\begin{tabular}{|c|c|}
\hline Formula weight & 1826.82 \\
\hline Temperature & $293(2) \mathrm{K}$ \\
\hline Wavelength & $0.71073 \AA$ \\
\hline Crystal system & Tetragonal \\
\hline Space group & $P 4 / m b m$ \\
\hline Unit cell dimensions & $\begin{array}{c}a=12.6369(18) \AA \\
b=12.6369(18) \AA \\
c=4.1378(8) \AA\end{array}$ \\
\hline Volume, Z & $660.77(2) \AA^{3}, 2$ \\
\hline Density (calculated) & $9.18118 \mathrm{~g} / \mathrm{cm}^{3}$ \\
\hline Absorption coefficient & $62.152 \mathrm{~mm}^{-1}$ \\
\hline$F(000)$ & 1556 \\
\hline Crystal size & $0.05 \times 0.01 \times 0.01 \mathrm{~mm}^{3}$ \\
\hline$\theta$ range & $2.28^{\circ}$ to $28.93^{\circ}$ \\
\hline Index ranges & $-16 \leq h \leq 17,-17 \leq k \leq 17,-5 \leq l \leq 3$ \\
\hline Reflections collected & 6117 \\
\hline Independent reflections & 526 \\
\hline Completeness to $\theta=28.93^{\circ}$ & $100 \%$ \\
\hline Refinement method & Full-matrix least-squares on $F^{2}$ \\
\hline Data/restraints/parameters & $526 / 0 / 34$ \\
\hline Goodness-of-fit & 1.076 \\
\hline Final $R$ indices $[>2 \sigma(\mathrm{I})]^{\mathrm{a}}$ & $R_{\mathrm{obs}}=0.0293, w R_{\mathrm{obs}}=0.0671$ \\
\hline Extinction coefficient & $0.00082(15)$ \\
\hline Largest diff. peak and hole & 2.327 and $-1.878 \mathrm{e} \cdot \AA^{-3}$ \\
\hline
\end{tabular}

Table 3. Atomic coordinates $\left(\times 10^{4}\right)$ and equivalent isotropic displacement parameters $\left(\AA^{2} \times 10^{3}\right)$ for $\mathrm{Yb}_{5} \mathrm{Co}_{4} \mathrm{Ge}_{10}$ at $296(2)$ $K$ with estimated standard deviations in parentheses.

\begin{tabular}{ccccc}
\hline Label & $\mathrm{x}$ & $\mathrm{y}$ & $\mathrm{z}$ & $\mathrm{U}_{\mathrm{eq}}{ }^{*}$ \\
\hline Yb1 & 0 & 0 & 0 & $6(1)$ \\
Yb2 & $1762(4)$ & $6762(4)$ & 5000 & $6(1)$ \\
Yb3 & $6113(4)$ & $1113(4)$ & 5000 & $7(1)$ \\
Co & $2453(1)$ & $255(1)$ & 0 & $5(1)$ \\
Ge1 & $688(1)$ & $5688(1)$ & 0 & $6(1)$ \\
Ge2 & $1554(1)$ & $1991(1)$ & 0 & $8(1)$ \\
Ge3 & $1640(1)$ & $56(1)$ & 5000 & $8(1)$ \\
\hline
\end{tabular}

${ }^{*} U_{e q}$ is defined as one third of the trace of the orthogonalized $U_{i j}$ tensor.

Table 4. Anisotropic displacement parameters $\left(\AA^{2} \times 10^{3}\right)$ for $\mathrm{Yb}_{5} \mathrm{Co}_{4} \mathrm{Ge}_{10}$ with estimated standard deviations in parentheses.

\begin{tabular}{ccccccc}
\hline Label & $\mathrm{U}_{11}$ & $\mathrm{U}_{22}$ & $\mathrm{U}_{33}$ & $\mathrm{U}_{12}$ & $\mathrm{U}_{13}$ & $\mathrm{U}_{23}$ \\
\hline $\mathrm{Yb} 1$ & $7(3)$ & $7(3)$ & $4(1)$ & 0 & 0 & 0 \\
$\mathrm{Yb} 2$ & $7(3)$ & $7(3)$ & $3(1)$ & $-1(1)$ & 0 & 0 \\
$\mathrm{Yb} 3$ & $8(3)$ & $8(3)$ & $5(4)$ & $-1(1)$ & 0 & 0 \\
$\mathrm{Co}$ & $6(1)$ & $6(1)$ & $4(1)$ & $-1(1)$ & 0 & 0 \\
$\mathrm{Ge} 1$ & $7(5)$ & $7(5)$ & $5(1)$ & $-1(1)$ & 0 & 0 \\
$\mathrm{Ge} 2$ & $6(1)$ & $8(1)$ & $11(1)$ & 0 & 0 & 0 \\
$\mathrm{Ge} 3$ & $8(1)$ & $14(1)$ & $3(1)$ & $-2(1)$ & 0 & 0 \\
\hline
\end{tabular}

The anisotropic displacement factor exponent takes the form: $-2 \pi^{2}\left[h^{2} a *^{2} U_{11}\right.$ $\left.+\cdots+2 \mathrm{hka}^{*} \mathrm{~b} * \mathrm{U}_{12}\right]$

Table 5. Selected bond lengths $[\AA ̊]$ for $\mathrm{Yb}_{5} \mathrm{Co}_{4} \mathrm{Ge}_{10}$ at 296(2) $K$ with estimated standard deviations in parentheses.

\begin{tabular}{cccc}
\hline Label & Distances & Label & Distances \\
\hline Yb1-Ge3 & $2.9300(9)$ & Yb3-Co & $3.2487(12)$ \\
Yb1-Co & $3.1167(15)$ & Co-Ge3 & $2.3232(9)$ \\
Yb2-Ge1 & $2.8217(12)$ & Co-Ge2 & $2.3603(19)$ \\
Yb2-Ge3 & $2.9527(13)$ & Co-Ge1 & $2.4112(17)$ \\
Yb2-Ge2 & $2.9814(10)$ & Ge1-Ge1 & $2.4620(3)$ \\
Yb2-Co & $2.9815(11)$ & Ge2-Ge2 & $2.5980(2)$ \\
Yb3-Ge1 & $3.1228(8)$ & Ge2-Ge3 & $2.9362(12)$ \\
Yb3-Ge3 & $3.2002(13)$ & Ge3-Ge3 & $2.9341(17)$ \\
Yb3-Ge2 & $3.2137(11)$ & & \\
\hline
\end{tabular}

\section{Results and Discussion}

\subsection{Structure Refinement of $\mathrm{Yb}_{5} \mathrm{Co}_{4} \mathrm{Ge}_{10}$}

The atomic parameters of $\mathrm{Sc}_{5} \mathrm{Co}_{4} \mathrm{Si}_{10}$ [1] were taken as starting parameters and the structure was refined using SHELXL-97 (full-matrix least-squares on $F^{2}$ ) [43] with anisotropic atomic displacement parameters for all atoms. As a check for the correct composition, the occupancy parameters were refined in a separate series of leastsquares cycles. Our data confirms the previous X-ray powder data [5], but the atomic positions have been refined with higher precision. Single crystals of $\mathrm{Yb}_{5} \mathrm{Co}_{4} \mathrm{Ge}_{10}$ 
from different synthesis batches were used for the data collection. In the first step of refinement on the single crystal data collected shows that $\mathrm{Yb}_{5} \mathrm{Co}_{4} \mathrm{Ge}_{10}$ crystallizes in a primitive tetragonal lattice $(P 4 / \mathrm{mbm})$ within the $\mathrm{Sc}_{5} \mathrm{Co}_{4} \mathrm{Si}_{10}$ type structure and lattice constants are $a=b=$ 12.6369 (18) $\AA$ and $c=4.1378$ (8) $\AA$. This refinement resulted in seven crystallographical positions (three $\mathrm{Yb}$, one $\mathrm{Co}$ and three $\mathrm{Ge}$ ) in the $\mathrm{Yb}_{5} \mathrm{Co}_{4} \mathrm{Ge}_{10}$ structure. The data collection and structure refinement for $\mathrm{Yb}_{5} \mathrm{Co}_{4} \mathrm{Ge}_{10}$ are listed in Table 2.

The standard atomic positions and isotropic atomic displacement parameters of this compound are collected in Table 3. The anisotropic displacement parameters and important bond lengths are listed in Tables 4 and 5, respectively. Further information on the structure refinements is available from: Fachinformationszentrum Karlsruhe, D-76344 Eggenstein-Leopoldshafen (Germany), by quoting the Registry Nos. CSD-425832.

\subsection{Crystal Chemistry of $\mathrm{Yb}_{5} \mathrm{Co}_{4} \mathrm{Ge}_{10}$}

The crystal structure of $\mathrm{Yb}_{5} \mathrm{Co}_{4} \mathrm{Ge}_{10}$ along $c$-axis is shown in Figure 2.

$\mathrm{Yb}_{5} \mathrm{Co}_{4} \mathrm{Ge}_{10}$ crystallizes in the primitive tetragonal $\mathrm{Sc}_{5} \mathrm{Co}_{4} \mathrm{Si}_{10}$ type structure (space group $\mathrm{P} 4 / \mathrm{mbm}$ ). Crystal structure of $\mathrm{Yb}_{5} \mathrm{Co}_{4} \mathrm{Ge}_{10}$ is composed of a complex $\left[\mathrm{Co}_{4} \mathrm{Ge}_{12}\right]$ polyanion network with three types of one dimensional channels, showed along the $c$-axis (Figure 2), in which $\mathrm{Yb}$ atoms are embedded. The cages are shared through the corners of $\mathrm{Co}$ and Ge form pentagonal and hexagonal rings and resulted in a three dimensional network. The pentagonal and hexagonal rings are occupied with $\mathrm{Yb} 2$ and $\mathrm{Yb} 3$ atoms, respectively. These rings are connected through $\mathrm{Co}$ and $\mathrm{Ge}$ in $a b$ plane and resulted in another large 8-membered ring, which is occupied by large $\mathrm{Yb} 1$ atoms. A detailed crystal structure description of the compounds crystallizing in the $\mathrm{Sc}_{5} \mathrm{Co}_{4} \mathrm{Si}_{10}$ was reported as an example of the $\mathrm{Yb}_{5} \mathrm{Ni}_{4} \mathrm{Ge}_{10}$ compound [2].

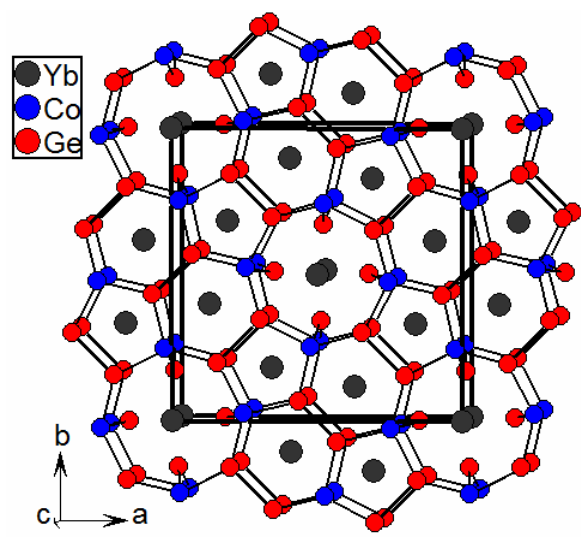

Figure 2. The crystal structure of $\mathrm{Yb}_{5} \mathrm{Co}_{4} \mathrm{Ge}_{10}$ as viewed along the $c$-axis; the unit cell is outlined as block solid lines.
Crystallographically there are three different $\mathrm{Yb}$-atoms are present in $\mathrm{Yb}_{5} \mathrm{Co}_{4} \mathrm{Ge}_{10}$. All three $\mathrm{Yb}$-coordination environments are significantly different. The $\mathrm{Yb} 1$ atom is located at the center of a cage consisting of $12 \mathrm{Ge}$ and 4 $\mathrm{Co}$ atoms forming a cage as $\mathrm{Yb}\left[\mathrm{Ge}_{12} \mathrm{Co}_{4}\right]$, $\mathrm{Yb} 2$ atoms are surrounded by eight $\mathrm{Ge}$ and four $\mathrm{Co}$ forming as $\mathrm{Yb}$ $\left[\mathrm{Ge}_{8} \mathrm{Co}_{4}\right]$ and $\mathrm{Yb} 3$ atoms are surrounded by fourteen atoms, $\mathrm{Yb}\left[\mathrm{Ge}_{10} \mathrm{Co}_{4}\right]$. The $\mathrm{Yb}-\mathrm{Ge}$ and $\mathrm{Yb}-\mathrm{Co}$ bond lengths in $\mathrm{Yb}_{5} \mathrm{Co}_{4} \mathrm{Ge}_{10}$ are in the wide range (2.8218 (9) $\AA$ to 3.2138 (10) $\AA$ for $\mathrm{Yb}-\mathrm{Ge}$ and 2.9815 (11) $\AA$ to 3.2488 (12) $\AA$ for $\mathrm{Yb}-\mathrm{Co}$ ) due to the different size of $\mathrm{Yb}$ coordination environments. The average distance obtained for $\mathrm{Yb} 3-\mathrm{Co}$, 3.2488 (12) $\AA$, is longer than the corresponding distance for Yb1-Co and Yb2-Co with 3.1167 (16) and 2.9815 (11) $\AA$, respectively. Similarly, the average bond distance for the $\mathrm{Yb} 3-\mathrm{Ge}$ is $3.1754 \AA$, is also longer than the corresponding distance for $\mathrm{Yb} 1-\mathrm{Ge}$ and $\mathrm{Yb} 2-\mathrm{Ge}$ with 3.0175 and $2.9343 \AA$, respectively. Similar kinds of bonding behavior were observed in the mixed valent $\mathrm{Yb}_{5} \mathrm{Ni}_{4} \mathrm{Ge}_{10}$ as well [2]. Since Katoh et al. observed the mixed valent $\mathrm{Yb}$ in $\mathrm{Yb}_{5} \mathrm{Co}_{4} \mathrm{Ge}_{10}$ based on the magnetic susceptibility measurements [22], our crystallographic data suggests the $\mathrm{Yb} 1$ and $\mathrm{Yb} 2$ atoms are mostly in the trivalent state and $\mathrm{Yb} 3$ in the divalent state. Considering the fact that divalent $\mathrm{Yb}$ is larger in size (1.86 $\AA$ ) $[46,47]$ compared to trivalent $\mathrm{Yb}(1.66 \AA)[46,47], \mathrm{Yb} 3$ prefer to be in large cage and others ( $\mathrm{Yb} 1$ and $\mathrm{Yb} 2$ ) are in the smaller cages.

We also compared the covalent radii and the unit cell volume four $\mathrm{Yb}$ based compounds reported in this family, as shown in Figure 3. The cell volume of the compounds increases as the covalent radii of the transition metals except in case of Co where there is drop in the cell volume. The drop in the cell volume for Co analogue is due to the major contribution of small size trivalent $\mathrm{Yb}$ atoms which was already confirmed in the magnetic susceptibility of two compounds where $\mathrm{Yb}_{5} \mathrm{Ni}_{4} \mathrm{Ge}_{10}$ has only $78 \% \mathrm{Yb}^{3+}$ and $\mathrm{Yb}_{5} \mathrm{Co}_{4} \mathrm{Ge}_{10}$ has $94 \% \mathrm{Yb}^{3+}$.

The comparison of covalent radii in Figure 3 also suggests that the metals like $\mathrm{Fe}, \mathrm{Ru}, \mathrm{Os}, \mathrm{Pt}$ and $\mathrm{Pd}$ are

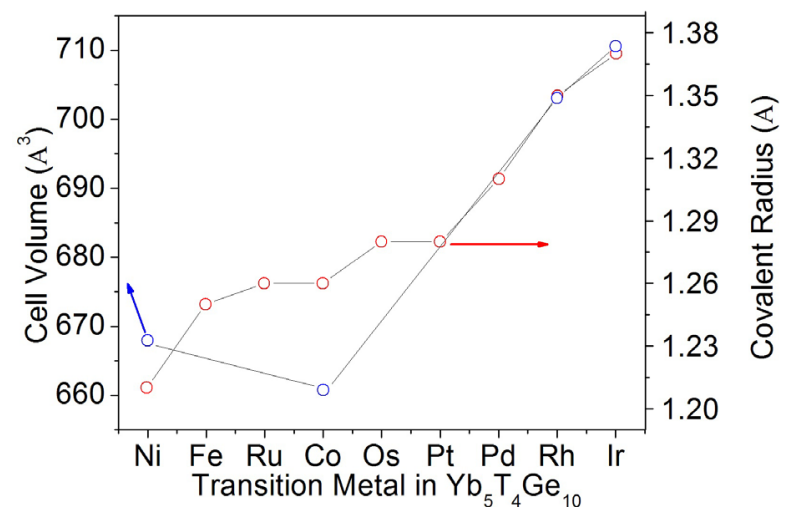

Figure 3. Comparison of the cell volume and covalent radii of transition metals in the $\mathrm{Yb}_{5} \mathbf{T}_{4} \mathrm{G}_{\mathrm{e} 10}$ family. 
suitable candidates for the formation $\mathrm{Yb}_{5} \mathrm{~T}_{4} \mathrm{Ge}_{10}$ compounds because the covalent radii of these metals are within the range of the reported compounds. This assumption can also be supported by the fact that $\mathrm{Yb}$ has the ability to show mixed valent compounds to stabilize the compounds.

\section{Concluding Remarks}

High quality single crystals of $\mathrm{Yb}_{5} \mathrm{Co}_{4} \mathrm{Ge}_{10}$ were obtained from the metal flux technique and the crystal structure of $\mathrm{Yb}_{5} \mathrm{Co}_{4} \mathrm{Ge}_{10}$ was studied using single crystal X-ray diffraction. Metal flux technique has been proved as vital synthesis method to obtain high quality single crystals. An absolute structure-property relation can be established by understanding the crystal structure from the single crystal X-ray data. Our study opens a lot of scope to find the crystal structure of the compounds which have not been studied as listed in Table 1 and the synthesis of new compounds as expected based on covalent radii comparison of transition metals.

\section{Acknowledgements}

We thank Prof. C. N. R. Rao for his support and guidance. Financial support from JNCASR, DST and Sheikh Saqr Laboratory is gratefully acknowledged. Udumula Subbarao thanks CSIR for research fellowship and Sebastian C. Peter thanks DST for Ramanujan Fellowship.

\section{REFERENCES}

[1] H. F. Braun, K. Yvon and R. M. Braun, " $\mathrm{Sc}_{5} \mathrm{~T}_{4} \mathrm{Si}_{10}(\mathrm{~T}=$ $\mathrm{Co}, \mathrm{Rh}, \mathrm{Ir})$ and $\mathrm{Y}_{5} \mathrm{~T}_{4} \mathrm{Ge}_{10}(\mathrm{~T}=\mathrm{Os}$, Ir) with a New Tetragonal Structure Type," Acta Crystallographica Section $B$, Vol. 36, No. 10, 1980, pp. 2397-2399. doi: $10.1107 / \mathrm{S} 0567740880008825$

[2] S. C. Peter, S. Rayaprol, M. C. Francisco and M. G. Kanatzidis, "Crystal Structure and Properties of $\mathrm{Yb}_{5} \mathrm{Ni}_{4} \mathrm{Ge}_{10}$," European Journal of inorganic Chemistry, Vol. 2011, No. 26, 2011, pp. 3963-3968. doi:10.1002/ejic.201100350

[3] K. Ghosh, S. Ramakrishnan, A. D. Chinchure, K. Jonason, V. R. Marathe, G. Chandra and S. Shah, "Heat-Capacity Studies in the $\mathrm{Y}_{5-x} \mathrm{Dy}_{x} \mathrm{Os}_{4} \mathrm{Ge}_{10}$ System," Physical Review $B$, Vol. 51, No. 17, 1995, pp. 11656-11663. doi:10.1103/PhysRevB.51.11656

[4] K. Ghosh, S. Ramakrishnan and G. Chandra, "Magnetism in the $R_{5} \operatorname{Ir}_{4} \mathrm{Si}_{10}(R=$ Ho and Er) Systems," Physical Review B, Vol. 48, No. 6, 1993, pp. 4152-4155. doi:10.1103/PhysRevB.48.4152

[5] G. Venturini, M. Méot Meyer, E. McRae, J. F. Maréché and B. Roques, "Vingt Nouveaux Germaniures Ternaires $\mathrm{TR}_{5} \mathrm{~T}_{4} \mathrm{Ge}_{10}$ de Metaux tr des Terres Rares et $\mathrm{T}=\mathrm{Co}, \mathrm{Rh}$, Ir. Supraconductivite de $\mathrm{Lu}_{5} \mathrm{Rh}_{4} \mathrm{Ge}_{10}$ et $\mathrm{Lu}_{5} \mathrm{Ir}_{4} \mathrm{Ge}_{10}$," $M a$ terials Research Bulletin, Vol. 59, No. 12, 1984, pp. 16471652. doi:10.1016/0025-5408(84)90242-3

[6] H. F. Braun, G. Burri and L. Rinderer, "Partial Phase
Diagram of the System Sc-Rh-Si," Journal of the Less Common Metals, Vol. 68, No. 1, 1979, pp. 1-8. doi:10.1016/0022-5088(79)90281-9

[7] O. I. Bodak, O. L. Sologub, P. Y. Zavalii and V. E. Zavodnik, "Crystal Structure of the Compound $\mathrm{Ho}_{5} \mathrm{Os}_{4} \mathrm{Ge}_{10}$," Russian Metallurgy (Metally), Vol. 6, 1991, pp. 156-158.

[8] O. I. Bodak and O. L. Sologub, "The Ho-Os-Ge System," Russian Journal of Inorganic Chemistry, Vol. 36, 1991, pp. 1353-1355.

[9] O. L. Sologub, K. Hiebl, P. Rogl and H. Noël, "Magnetic Behavior of Holmium-Platinum Group Metal-Germanium Ternary Alloys," Journal of Alloys and Compounds, Vol. 245, No. 1-2, 1996, pp. L13-L17. doi:10.1016/S0925-8388(96)02409-7

[10] L. S. Hausermannberg and R. N. Shelton, "Low Temperature Heat Capacity Study of Superconducting Ternary Silicides with the $\mathrm{Sc}_{5} \mathrm{Co}_{4} \mathrm{Si}_{10}$-Type Structure," Physica $B+C$, Vol. 135, No. 1-3, 1985, pp. 400-404. doi:10.1016/0378-4363(85)90516-9

[11] N. G. Patil and S. Ramakrishnan, "Magnetism in the $R_{5} T_{4} \mathrm{Sn}_{10}(R=\mathrm{Ce}, \mathrm{Pr}$, and $\mathrm{Nd} ; T=\mathrm{Rh}$ and Ir) System," Physical Review B, Vol. 56, No. 6, 1997, pp. 3360-3371. doi:10.1103/PhysRevB.56.3360

[12] H. D. Yang, R. N. Shelton and H. F. Braun, "Superconductivity and Electronic Instability at High Pressure in $\mathrm{Sc}_{5} \mathrm{Co}_{4} \mathrm{Si}_{10}$-Type Compounds," Physical Review B, Vol. 33, No. 7, 1986, pp. 5062-5065. doi:10.1103/PhysRevB.33.5062

[13] H. D. Yang, P. Klavins and R. N. Shelton, "Low-Temperature Physical Properties of $R_{5} \mathrm{Ir}_{4} \mathrm{Si}_{10}(R=\mathrm{Dy}, \mathrm{Ho}, \mathrm{Er}$, Tm, and Yb) Compounds," Physical Review B, Vol. 43, No. 10, 1991, pp. 7688-7694. doi:10.1103/PhysRevB.43.7688

[14] S. Ramakrishnan, K. Ghosh and G. Chandra, "Magnetism and Superconductivity in $\mathrm{Sc}_{5-x} \mathrm{Dy}_{x} \mathrm{Ir}_{4} \mathrm{Si}_{10}$ Alloys," Physical Review B, Vol. 46, No. 5, 1992, pp. 2958-2963. doi:10.1103/PhysRevB.46.2958

[15] G. Venturini, B. Malamana and B. Roques, "New Rare Earth-Transition Metal Stannides with $\mathrm{Sc}_{5} \mathrm{Co}_{4} \mathrm{Si}_{10}$ and $\mathrm{TiMnSi}_{2}$ - Type Structures. Atomic Size Effects on Their Stability," Materials Research Bulletin, Vol. 24, No. 9, 1989, pp. 1135-1139. doi:10.1016/0025-5408(89)90071-8

[16] R. E. Gladyshevskii, E. Parthé, O. L. Sologub and P. S. Salamakha, "Crystal Structure of Pentaholmium Tetrarhodium Decagermanium, $\mathrm{Ho}_{5} \mathrm{Rh}_{4} \mathrm{Ge}_{10}$ with $\mathrm{Sc}_{5} \mathrm{Co}_{4} \mathrm{Si}_{10}$ Type," Zeitschrift für Kristallographie, Vol. 203, No. 1, 1993, pp. 115-116. doi:10.1524/zkri.1993.203.Part-1.115

[17] L. S. Hausermannberg and R. N. Shelton, "Low-Temperature Heat-Capacity Study of Superconducting Ternary Silicides and Germanides with the $\mathrm{Sc}_{5} \mathrm{Co}_{4} \mathrm{Si}_{10}$-Type Structure," Physical Review B: Condensed Matter, Vol. 35, No. 13, 1987, pp. 6659-6664. doi:10.1103/PhysRevB.35.6659

[18] H. F. Braun and C. U. Segre, "The Superconductivity of $\mathrm{Sc}_{5} \mathrm{~T}_{4} \mathrm{Si}_{10}(\mathrm{~T}=\mathrm{Co}, \mathrm{Rh}, \mathrm{Ir})$ and Isomorphous Compounds," Solid State Communications, Vol. 35, No. 10, 1980, pp. 735-738. doi:10.1016/0038-1098(80)91065-0

[19] N. G. Patil and S. Ramakrishnan, "Magnetism and Superconductivity in $M_{5} \mathrm{Rh}_{4} \mathrm{Ge}_{10}(M=\mathrm{Gd}, \mathrm{Tb}, \mathrm{Dy}, \mathrm{Ho}, \mathrm{Er}$, 
Tm, Lu, and Y)," Physical Review B, Vol. 59, No. 14, 1999, pp. 9581-9589. doi:10.1103/PhysRevB.59.9581

[20] M. Kolenda, M. Hofmann, J. Leciejewicz, B. Penc and A. Szytula, "Neutron-Diffraction Studies of $R_{5} \mathrm{Rh}_{4} \mathrm{Ge}_{10}(R=\mathrm{Tb}$, Ho, Er) Compounds," Applied Physics A, Vol. 74, No. 1, 2002, pp. S769-S771. doi:10.1007/s003390201582

[21] S. Ramakrishnan, K. Ghosh and G. Candra, "Antiferromagnetism in the $\mathrm{Dy}_{5} \mathrm{Ir}_{4} \mathrm{Si}_{10}$ System," Physical Review B, Vol. 45, No. 18, 1992, pp. 10769-10770. doi:10.1103/PhysRevB.45.10769

[22] K. Katoh, T. Tsutsumi, K. Yamada, G. Terui, Y. Niide and A. Ochiai, "Magnetic and Transport Properties of $\mathrm{Yb}_{5} \mathrm{~T}_{4} \mathrm{Ge}_{10}$ (T = Co, Rh, Ir)," Physica B: Condensed Matter, Vol. 373, No. 1, 2006, pp. 111-119. doi:10.1016/j.physb.2005.11.098

[23] P. Villars and K. Cenzual, "Pearson's Crystal Data-Crystal Structure Database for Inorganic Compounds," ASM International, Materials Park, 2010.

[24] Inorganic Crystal Structure Database, "Fachinformationszentrum Karlsruhe GmbH: Eggenstein-Leopoldshafen," Karlsruhe, 2012.

[25] B. Kindler, D. Finsterbusch, R. Graf and F. Ritter, "MixedValence Transition in $\mathrm{YbInCu}_{4}$," Physical Review B, Vol. 50, No. 2, 1994, pp. 704-707. doi:10.1103/PhysRevB.50.704

[26] E. Bauer, "Anomalous Properties of $\mathrm{Ce}-\mathrm{Cu}-$ and $\mathrm{Yb}-\mathrm{Cu}-$ Based Compounds," Advances in Physics, Vol. 40, No. 4, 1991, pp. 417-534. doi:10.1080/00018739100101512

[27] P. Wachter, "Handbook on the Physics and Chemistry of Rare Earths," Elsevier Science, Amsterdam, 1994, p. 177.

[28] Y. Matsumoto, S. Nakatsuji, K. Kuga, Y. Karaki, N. Horie, Y. Shimura, T. Sakakibara, A. H. Nevidomskyy and P. Coleman, "Quantum Criticality without Tuning in the Mixed Valence Compound B-YbAlB 4 ," Science, Vol. 331, No. 6015, 2011, pp. 316-319. doi:10.1126/science.1197531

[29] U. Subbarao and S. C. Peter, "Crystal Structure of $\mathrm{YbCu}_{6} \mathrm{In}_{6}$ and Mixed Valence Behavior of $\mathrm{Yb}$ in $\mathrm{YbCu}_{6-X} \operatorname{In}_{6+X}(X=$ 0, 1, and 2) Solid Solution," Inorganic Chemistry, Vol. 51, No. 11, 2012, pp. 6326-6332. doi:10.1021/ic300552w

[30] S. Ernst, S. Kirchner, C. Krellner, C. Geibel, G. Zwicknagl, F. Steglich and S. Wirth, "Emerging Local Kondo Screening and Spatial Coherence in the Heavy-Fermion Metal $\mathrm{YbRh}_{2} \mathrm{Si}_{2}$," Nature, Vol. 474, 2011, pp. 362-366. doi:10.1038/nature10148

[31] U. Subbarao and S. C. Peter, "Crystal Growth and Properties of $\mathrm{YbCuGa}_{3}$ : First Monoclinic System in the RETX $_{3}$ Family," Crystal Growth \& Design, Vol. 13, No. 2, 2013, pp. 953-959. doi:10.1021/cg301765f

[32] U. Subbarao, M. Gutmann and S. C. Peter, "New Structure Type in the Mixed-Valent Compound $\mathrm{YbCu}_{4} \mathrm{Ga}_{8}$," Inorganic Chemistry, Vol. 52, No. 4, 2013, pp. 22192227. doi:10.1021/ic302688n

[33] S. C. Peter, S. M. Disseler, J. N. Svensson, P. Carretta and M. J. Graf, "Yb $\mathrm{HiGe}_{4}-\mathrm{A}$ Yb Mixed Valent Zintl Phase with Strong Electronic Correlations," Journal of
Alloys and Compounds, Vol. 516, No. 516, 2012, pp. 126133. Doi: 10.1016/J.Jallcom.2011.11.148

[34] S. C. Peter and M. G. Kanatzidis, "The New Binary Intermetallic $\mathrm{YbGe}_{2.83}$," Journal of Solid State Chemistry, Vol. 183, No. 9, 2010, pp. 2077-2081. doi: $10.1016 /$ J.Jssc. 2010.06.022

[35] S. C. Peter, J. Salavador, J. B. Martin, W. Wong-Ng and M. G. Kanatzidis, "New Intermetallics $\mathrm{YbAu}_{2} \mathrm{In}_{4}$ and $\mathrm{Yb}_{2} \mathrm{Au}_{3} \mathrm{In}_{5}$," Inorganic Chemistry, Vol. 49, No. 22, 2010, pp. 10468-10474. doi:10.1021/ic101502e

[36] M. Chondroudi, S. C. Peter, C. D. Malliakas, M. Balasubramanian, Q. Li and M. G. Kanatzidis, "Yb ${ }_{3} \mathrm{AuGe}_{2} \mathrm{In}_{3}$ : An Ordered Variant of the YbAuIn Structure Exhibiting Mixed-Valent Yb Behavior," Inorganic Chemistry, Vol. 50, No. 4, 2011, pp. 1184-1193. doi:10.1002/ejic.201100350

[37] S. C. Peter, S. Rayaprol, M. C. Francisco and M. G. Kanatzidis, "Crystal Structure and Properties of $\mathrm{Yb}_{5} \mathrm{Ni}_{4} \mathrm{Ge}_{10}$," European Journal of Inorganic Chemistry, Vol. 2011, No. 26, 2011, pp. 3963-3968. doi:10.1021/ja204971n

[38] S. C. Peter, M. Chondroudi, C. D. Malliakas, M. Balasubramanian and M. G. Kanatzidis, "Anomalous Thermal Expansion in the Square-Net Compounds $R E_{4} \mathrm{TGe}_{8}(R E=$ $\mathrm{Yb}, \mathrm{Gd} ; \mathrm{T}=\mathrm{Cr}-\mathrm{Ni}, \mathrm{Ag})$," Journal of the American Chemical Society, Vol. 133, No. 35, 2011, pp. 13840-13843. doi:10.1021/ja204971n

[39] S. C. Peter, S. Sarkar and M. G. Kanatzidis, "Metallic $\mathrm{Yb}_{2} \mathrm{AuGe}_{3}$ : An Ordered Superstructure in the $\mathrm{AlB}_{2}$-Type Family with Mixed-Valent $\mathrm{Yb}$ and a High-Temperature Phase Transition," Inorganic Chemistry, Vol. 51, No. 20 , 2012, pp. 10793-10799. doi:10.1021/ic301197w

[40] SAINT, "Bruker AXS," 6.02 ed., SAINT, Madison, 1999.

[41] G. M. Sheldrick, SADABS, "Empirical Absorption Correction Program," University of Göttingen, Göttingen, 1997.

[42] L. J. Farrugia, "WinGX Suite for Small-Molecule SingleCrystal Crystallography," Journal of Applied Crystallography, Vol. 32, No. 4, 1999, pp. 837-838. doi:10.1107/S0021889899006020

[43] G. M. Sheldrick, "A Short History of SHELX," Acta Crystallographica Section A, Vol. A64, No. 1, 2008, pp. 112-122. doi:10.1107/S0021889899006020

[44] SHELXTL 5.10, "Bruker Analytical X-Ray Systems," Madison, 1997.

[45] Crystal Impact, “Crystal Impact GbR,” Version 3.g, Crystal Impact, Bonn, 2011.

[46] R. T. Sanderson, "Electronegativity and Bond Energy," Journal of the American Chemical Society, Vol. 105, No. 8, 1983, pp. 2259-2261. doi:10.1021/ja00346a026

[47] F. H. Allen, O. Kennard, D. G. Watson, L. Brammer, A. G. Orpen and R. Taylor, "Table of Bond Lengths Determined by X-Ray and Neutron Diffraction," Journal of the American Chemical Society, Perkin Transactions 2, Vol. 12, 1987, pp. S1-S19. doi: $10.1039 / \mathrm{p} 298700000 \mathrm{~s} 1$ 